\title{
Pelayanan Publik pada Sektor Komunikasi
}

\author{
Mohamad Subur Drajat
}

\begin{abstract}
For the most part of society, the quality of public service is far from hope. There were so many problems concerning public service today. One among them was the lack of government capabilities to deal with a very large area and numerous characters. For communication studies, a good public service was influenced by an excellent communication system. There are factors to be deal with: the optimum performance of Public Relations, equal distribution of communication/information, easy access for public, easy access for information, stabilized political situation, and the same pattern of thinking between government and communication manager.
\end{abstract}

Kata kunci: publik, layanan publik, komunikasi, kehumasan

\section{Pendahuluan}

Masyarakat kita saat ini masih menganggap bahwa kualitas pelayanan pemerintah terhadap kepentingan masyarakat masih rendah. Pelayanan publik yang diberikan pemerintah lebih buruk dibandingkan dengan pelayanan yang diberikan oleh sektor swasta. Pegawai Negeri Sipil (PNS) yang diangkat pemerintah dan dipekerjakan untuk memberikan pelayanan kepada masyarakat ternyata belum memberikan pelayan terbaik kepada masyarakat. Pemerintah menaikkan gaji PNS sebagai upaya untuk meningkatkan pelayanan kepada masyarakat ternyata juga tidak membuktikan peningkatan pelayanan.

Tidak meningkatnya pelayanan yang diterima masyarakat seolah-olah sudah menjadi hal yang biasa. Pelayanan pendidikan yang seharusnya menjadi prioritas masyarakat malah tersisihkan oleh kepentingan lain. Padahal, pendidikakan menjadi modal utama kemajuan bangsa. Keluhan masyarakat mulai dari pembuatan KTP, pelayanan air bersih, fasilitas jalan, fasilitas tranportasi yang tidak nyaman, kesulitan mendapatkan minyak tanah, adalah hanya sebagian akibat dari pelayanan pemerintah yang tidak optimal.

Masyarakat menilai, antri minyak tanah yang berjam-jam dan kelangkaan gas pada awal tahun 2008 sebagai bukti pemerintah tidak bisa memperhatikan kebutuhan masyarakat kecil/ pemerintah tidak bisa memberikan pelayanan terbaik kepada masyarakat. Anggota kominisi B DPRD Jabar, Yazid Salman, menilai kasus ini sebagai akibat kebijaksanaan pemerintah yang tidak tuntas. Ia menilai, program konversi minyak tanah ke gas, gagal. "Saya kira, kebijakan itu harus serius ditangani dari hulu sampai hilir". Sosialisasi yang dilakukan pemerintah masih sangat kurang. Padahal sosialisasi sangat penting karena kebijakan konversi itu membutuhkan dukungan 
dari masyarakat (Pikiran Rakyat, 5 Januari 2008). Kenyataan ini menunjukkan bahwa pelayanan publik yang dilakukan pemerintah belum memuaskan, malah jadi menyusahkan.

Sangat jarang pejabat pemerintah mempunyai kemampuan sosialisasi edukasi dengan tujuan jangka panjang. Padahal, sosialisasi itu untuk mendukung program pelayanan publik. Masyarakat seringkali tidak mendapatkan informasi yang tuntas dan jelas dari sosialisasi yang disampaikan pemerintah. Informasi yang disampaikan hanya sebatas pengetahuan saja, tidak sampai pada perubahan sikap sesuai dengan yang diinginkan oleh pemerintah. Seharusnya, komunikasi yang berhasil adalah adanya perubahan sikap pada komunikan sesuai dengan keinginan komunikator.

Resistensi yang tinggi dari masyarakat yang menolak program pemerintah memang bisa menjadi penghambat program sosialisasi yang dilakukan pemerintah. Pemerintah Daerah Jakarta meluncurkan program Busway sebagai upaya mengurangi masalah kemacetan (meningkatkan pelayanan publik pada sektor tranfortasi), dan program pembangungan Pembangkit Listrik Tenaga Sampah/PLTSa yang dilakukan pemerintah Kota Bandung merupakan sebagian contoh kegagalan sosialisasi yang dilakukan pemerintah. Kegagalan sosialisasi ini sama juga dengan kegagalan komunikasi yang dilakukan pemerintah.

Pemerintah kita mempunyai sejarah yang buruk dengan sistem komunikasi. Pemerintah pada masa Orde Baru memanfaatkan Departemen Penerangan sebagai kendaraan politik Golkar yang isi pesannya lebih banyak untuk kepentingan Golkar sebagai penguasa pemerintah. Kegagalan pemerintah dalam memberdayakan lembaga komunikasi ini membuat rapor pemerintah jelek, kondisi ini mempengaruhi sikap masyarakat dalam menerima informasi yang datang dari pemerintah. Situasi ini menyebabkan masyarakat lebih percaya dengan sumber informasi alternatif ketimbang sumber informasi resmi yang datang dari pemerintah.

Indikasi pemerintah belum menempatkan strategi pengelolaan informasi dan Public Rela- tions sebagai ujung tombak yang bisa meringankan pekerjaan pemerintah (pelayanan publik) bisa dilihat dari pernyataan mantan Menteri Negara Komunikasi, dan Informasi, Syamsul Muarif dalam seminar "One Stop Shopping for Public Relations", tahun 2003, yang diadakan Badan Esksekutif Mahasiswa UI, mengatakan bahwa budget operasional untuk departemennya sulit keluar. Jadi wajar apabila pelayanan publik yang diterima masyarakat masih dirasakan sangat rendah.

Agus Dwiyanto dkk (2003) dalam hasil penelitiannya tentang Governance and Decentralization Survey (GDS), mengemukakan, beberapa indikasi adanya pelayanan pemerintah kabupaten dan kota yang masih jauh dari prinsipprinsip tata pemerintah yang baik, antara lain : (a) belum adanya prinsip keadilan dan persamaan dalam praktik pelayanan publik yang ditandai oleh masih adanya diskriminasi menurut hubungan pertemanan, afiliasi politik, kesamaan etnis, dan agama dalam praktik publik; (b) rendahnya responsivitas pemerintah kabupaten dan kota dalam menanggapi keluhan dan kebutuhan masyarakat. Frekuensi keluhan masyarakat yang paling banyak adalah masalah sertifikat tanah dan yang terendah adalah masalah KTP; (c) rendahnya efisiensi dan efektivitas pelayan yang ditandai oleh adanya pelayanan yang lambat, tidak cepat dan tepat waktu, dan masih adanya biaya tambahan diluar biaya yang seharusnya; (d) masih adanya budaya rente birokrasi di mana sering terjadi praktek suap dan potongan yang kadang-kadang melebihi keuntungan dalam mengerjakan proyek-proyek pemerintah.

Masalah pelayanan publik yang masih sangat klasik adalah masyarakat sudah terbiasa/dipaksa mengikuti aturan bermain oknum pegawai pemerintah. Masyarakat, kalau ingin mengurus sesuatu dengan lancar dan cepat, berikanlah suatu imbalan. Kebiasaan jelek lainnya adalah masyarakat ingin serba cepat tidak mau antri sehingga merugikan orang lain. Kondisi demikian memang sangat dilematis, pelayan publik yang diharapkan terjadi secara profesional sudah terkontaminasi oleh kepentingan pribadi dan kebiasaan oknum masyarakat yang tidak terpuji. 
Terakreditasi Dirjen Dikti SK No. 56/DIKTI/Kep/2005

Masalah lainnya yang sering muncul pada pelayan publik adalah adanya kesenjangan antara kepentingan pemerintah (provider) dengan kepentingan masyarakat (consumer) yang seringkali berbeda. Heterogennya keberadaan masyarakat merupakan faktor yang bisa juga memunculkan permasalahan dalam kegiatan pelayanan publik. Pelayanan publik (public service) seharusnya bertujuan untuk memenuhi berbagai tuntutan dan kebutuhan masyarakat, baik sebagai individu, kelompok, dan status-status yang lainnya. Bentuk pelayanan seperti apakah yang layak diterima oleh masyarakat dan diberikan oleh pemerintah?

\section{Pelayanan Publik}

Konsep pelayanan publik diturunkan dari makna public service, yang berarti: "berbagai aktivitas yang bertujuan memenuhi kebutuhan masyarakat akan barang dan jasa" (Pamuji, 1999) dalam Napitupulu, 2007, 165). Konsep ini berpijak pada kepentingan masyarakat sebagai konsumen yang membutuhkan perhatian dan pelayanan. Menurut Ruslan (2003: 260), konsep pelayan publik berkaitan dengan jasa pelayanan yang dilaksanakan oleh perusahaan dalam upaya untuk memberikan rasa kepuasaan dan menumbuhkan kepercayaan pihak pelanggannya (konsumen). Pelayan tersebut juga membuat pihak konsumen merasa dirinya dipentingkan atau diperhatikan dengan baik dan wajar.

Dari dua konsep di atas, yang lebih dikedepankan adalah kepentingan/kepuasaan konsumen (masyarakat). Kepuasaan masyarakat yang diperoleh akan tergantung dari apa yang telah diberikan pemerintah pada rakyatnya dan bagaimana masyarakat memberikan respons. Dengan demikian, di tangan pemerintahlah tanggung jawab pelayanan terhadap berbagai kebutuhan masyarakat diletakan, melalui fungsi pelayanan yang baik pemerintah mendapatkan keribibilitas yang baik dari rakyat.

Standar pelayanan yang diberikan pemerintah pada masyarakat tidak bisa selamanya dijadikan sebagai standar pelayan yang baku, karena perkembangan sosial, budaya, dan teknologi yang terjadi pada masyarakat akan terus berubah. Sebuah pelayanan yang baik tentunya harus menyesuaikan dengan kondisi yang ada pada masyarakat. Ndraha (2000), menyebutkan tugas pelayanan pemerintah dalam memenuhi kebutuhan masyarakat sangat ditentukan oleh sistem nilai budaya pemerintah dan budaya masyarakat tersebut (Napitupulu, 2007: 166). Pelayanan publik yang baik dipengaruhi juga oleh adanya kondisi pemerintah yang sehat dalam arti adanya kemampuan pemerintah dalam mengatasi krisis ketidakpastian, adanya kestabilan politik, ekonomi dan perhatian penguasa pada sektor komunikasi.

Manusia dalam kehidupan kelompok dan interaksinya dengan orang lain, menginginkan beberapa nilai, yakni: kekuasaan, pendidikan, kesehatan, kasih sayang, kejujuran, keadilan serta nilai keseganan atau respek, (Harold Laswell, 1972 dalam Budiarjo,1996). Negara mempunyai tujuan untuk melindungi warga negaranya. Oleh karena itu negara dan pemerintah harus menjamin terpenuhinya berbagai kebutuhan dan kepentingan warganya secara adil dan merata. Pemerintahan yang baik tentunya pemerintahan yang mengedepankan kebutuhan warganya.

Setiap instansi pemerintah yang berkaitan erat dengan pelayanan publik seharusnya mempunyai unit yang bertugas untuk memfasilitasi segala kebutuhan publiknya. Tugas pemerintah menjadi lebih ringan dalam proses pemenuhan berbagai kebutuhan masyarakat manakala pemerintah mempunyai lembaga-lembaga yang sudah mempunyai mekanisme dan standar pelayanan yang diterima masyarakat. Instansi pemerintah juga harus bisa memberdayakan potensi komunikasi, termasuk potensi komunikasi yang sudah dimiliki secara alamiah oleh setiap individu. Al-Qur,an mengatakan, "Tuhan yang Maha pemurah, yang telah mengajarkan Al-Qur,an. Dia menciptakan manusia, yang mengajarinya pandai berbicara" (Ar-Rahman: 1-4). Manusia diberikan kelebihan kepandaian berbicara. Jadi, alangkah baiknya apabila manusia itu memfaatkan kelebihannya untuk kepentingan sesamanya.

Iklim komunikasi dalam pemerintahan merupakan hal yang perlu menjadi perhatian karena 
iklim komunikasi ikut mempengaruhi tercapai pelayanan publik yang memuaskan. Potensi komunikasi yang dimiliki para pejabat pemerintah dan pegawai pemerintah harus bisa dimanfaatkann untuk mengubah sikap dan perilaku masyarakat sebagai pemeran utama pembangunan. Kalau iklim komunikasi ini bisa diciptakan, dipertahankan, dan ditingkatkan, tentunya pelayanan publik pada sektor komunikasi yang dilakukan pemerintah bisa menjadi faktor utama dalam menciptakan pelayanan publik yang baik secara keseluruhan.

Ada beberapa faktor yang harus diperhatikan untuk bisa menciptakan pelayanan publik pada sektor komunikasi:

(1) Optimalkan lembaga humas

(2) Ciptakan pemerataan informasi

(3) Masyarakat diberikan kemudahan dalam mendapatkan informasi

(4) Terciptanya kondisi politik yang stabil dan adanya pola pikir pemerintah yang sama dengan pengelola komunikasi.

\subsection{Optimalkan Kinerja Lembaga Humas}

Ukuran keberhasilan pelayanan yang dilakukan pemerintah ditentukan oleh kepuasaan masyarakat sebagai penerima pelayanan. Kepuasaan pelayanan dicapai apabila masyarakat memperoleh pelayanan sesuai dengan yang dibutuhkan dan diharapkan mereka. Melihat ukuran keberhasilan itu, tentunya peluang pelayanan publik yang baik terletak pada humas karena salah satu pekerjaan humas adalah menampung aspirasi masyarakat sehingga humas bisa mengetahui sikap, opini, dan perilaku masyarakat. Keuntungan yang diperoleh adalah pemerintah sebelum mengonsep sebuah pelayanan/kebijakan bisa meminta pendapat humas mengenai bentuk pelayanan apa yang bisa diterima masyarakat. Widjaya, (1997: 60) mengatakan, pelaksanaan program kehumasan dilakukan dengan pendekatan kemasyarakatan, melalui mekanisme sosial-kultural. Susanto, $(1985,30)$, berpendapat pendekatan sosio-kultural dalam bidang komunikasi dapat menghasilkan suatu sikap senasib sepenanggungan bagi berbagai kelompok bangsa hingga tercapailah sukarela dalam pembangunan, karena masing-masing insan Indonesaia merasa dipunyai tempat berperan, dihargai, dan dalam proses penempatan kesatuan bangsa tersebut.

Kondisi masyarakat yang tersebar luas dan heterogennya keberadaan masyarakat menyulitkan para aparat pemerintah untuk mengetahui kebutuhan-kebutuhan masyarakatnya secara utuh dan lengkap. Tidak jarang kebutuhan-kebutuhan masyarakat yang sangat mendasar tidak bisa diketahui dan dipahami oleh pemerintah. Bisa saja persoalaan ini muncul karena masalah komunikasi. Pada kasus ini, lembaga humas bisa dimanfaatkan sebagai pengelola segala layanan-layanan komunikasi pemerintah dan kebutuhan-kebutuhan yang ada pada masyarakat untuk disampaikan pada pemerintah.

Sistem pemerintah yang demokratis sesuai dengan tujuan humas. Pemerintah demokratis yang sukses ditandai adanya upaya mempertahankan hubungan yang responsif dengan warga, berdasarkan pemahaman dan komunikasi dua arah yang saling menguntungkan (Cutlif, Center, Broom, 2005 : 386). Salah satu fungsi penting dalam kegiatan pelayanan publik adalah fungsi komunikasi yang menyalurkan informasi, baik dari pemerintah ke masyarakat, ataupun sebaliknya, dari masyarakat ke pemerintah. Melalui fungsi komunikasi, saran atau kritik tentang kinerja pelayanan pemerintah dapat diketahui. Dari situ kemudian pemerintah bisa mengukur diri seberapa jauh kinerjanya ditanggapi masyarakat. Hal ini bisa dilakukan dengan cara menciptakan komunikasi dua arah yang saling menguntungkan di antara keduanya. Humas harus bisa menciptakan komunikasi yang efektif, Oxley (1987 : 14) dalam Iriantara, 2004 : 61) mengatakan, "Publik relations/ humas yang efektif merupakan komunikasi yang efektif. Untuk mencapai hal tersebut peran lembaga humas harus diutamakan.

Humas pemerintah pada dasarnya tidak bersifat politis. Bagian humas di institusi pemerintah diupayakan untuk memublikasikan kebijakan-kebijakan pemerintah dan melayani 
Terakreditasi Dirjen Dikti SK No. 56/DIKTI/Kep/2005

opini-opini warga/masyarakat yang ditujukan pada pemerintah, seiring dengan tuntutan transparansi dari masyarakat terhadap pemerintah. Humas pemerintah bisa menjembatani keinginan masyarakat sekaligus sebagai salah satu pelayan komunikasi dari pemerintah. Widjaya, (1997 : 126), menandaskan, dalam alam demokrasi Pancasila, kehumasan harus mempunyai sifat membina dan mengembangkan partisipasi rakyat dan mendidik masyarakat sekitar hal-hal yang menyangkut kepentingan mereka. Demokrasi kita menuntut tumbuhnya kejujuran dan kebenaran di kalangan pemerintah dan masyarakat dalam bersama-sama mencapai tujuan negara.

Humas dimungkinkan untuk memberikan masukan dan saran pada pemerintah tentang segala informasi yang diperlukan dan memantau kemungkinan adanya reaksi masyarakat mengenai kebijakan pemerintah, baik yang sedang dilaksanakan, akan dilaksanakan, ataupun yang sedang disusun. Kepentingan pemerintah dengan masyarakat sebetulnya adalah hubungan kebijakan melalui wakil-wakilnya di Dewan Perwakilan Rakyat. Hanya saja, sebelum kebijakan itu disampaikan, pemerintah harus mampu menciptakan pemahaman terhadap masyarakat terhadap efektivitas setiap kebijakannya.

Dengan demikian, jauh sebelum kebijakan tersebut dibuat, pemerintah harus lebih dulu menciptakan pemahaman yang utuh dalam benak masyarakat. Pemahaman yang utuh dengan sendirinya diawali dengan pengembangan citra yang baik. Di sinilah peran humas dibutuhkan oleh pemerintah. Humas harus menjadi media pelayanan publik, sehingga pandangan yang mengatakan bahwa pemerintah kurang peduli terhadap kondisi masyarakat bisa diminimalkan.

Program humas yang dikembangkan adalah untuk memperbaiki jalur-jalur komunikasi yang telah ada dan menciptakan cara-cara baru untuk membentuk arus informasi dua arah dan saling pengertian. Tetapi, program humas yang dikembangkan tanpa disertai dukungan dari pemerintah bisa memunculkan citra negatif dan ini menurunkan kredibilitas kepercayaan masyarakat terhadap lembaga pemerintah.
Pemerintah harus percaya kepada humas sebagai lembaga yang mampu memberikan pemahaman kepada masyarakat, lembaga yang mampu mengubah opini, sikap, dan perilaku masyarakat. Pemahaman akan mudah diterima masyarakat apabila citra positiftelah dimiliki oleh pemerintah.

Pemerintah harus paham bahwa lembaga komunikasi/humas bukan hanya sekadar corong pemerintah saja seperti pada masa Orde Baru, tetapi memanfaatkan humas sebagai jembatan penghubung antara kepentingan pemerintah dengan kepentingan masyarakat. Humas harus bisa menampung aspirasi masyarakat untuk disampaikan pada aparatur pemerintah dan humas juga harus bisa menyampaikan kebijaksanaan pemerintah pada masyarakat. Oleh karena itu, humas bisa menjadi laboratorium kebijakan pemerintah atau sebagai laboratorium komunikasi pemerintah.

Untuk lebih mengoptimalkan komunikasi yang dilakukan pemerintah, Badan Koordinasi Kehumasan Pemerintah (Bakohumas) harus lebih diberdayakan. Badan ini harus bisa menjaga terpeliharanya hubungan harmonis antar lembaga pemerintah dan menciptakan komunikasi yang baik antara lembaga-lembaga pemerintah dengan masyarakat. Tugas Bakohumas adalah: (1) membantu Departemen Komunikasi dan Informasi dalam menetapkan kebijakan pembinaan hubungan yang lancar dan harmonis antara masyarakat dengan pemerintah; (2) mengadakan koordinasi, integrasi, sinkronisasi, dan kerjasama antara semua humas departemen/lembaga negara; (3) merencanakan dan melaksanakan kegiatankegiatan kehumasan sesuai dengan kebijakan pemerintah

Kerumitan pekerjaan pemerintah dalam melayani kepentingan publik bisa diminimalkan kalau memang pemerintah betul-betul bisa mengoptimalkan kinerja humasnya dan menjadikan Humas sebagai lembaga integral dari penyelenggaraan pelayanan publik. Oleh karena itu, sumber daya yang handal dan pelatihanpelatihan kehumasan menjadi harga mati untuk dikembangkan di setiap institusi pemerintah.

Prinsip kepuasaan masyarakat dalam proses 
pelayanan publik yang dilakukan pemerintah sangat penting karena hanya dengan memenuhi kebutuhan masyarakat keberadaan pemerintah itu diakui dan mendapatkan legitimasi serta kepercayaan dari rakyatnya. Sukses sebagai demokrasi yang diidamkan sepertinya bisa terwujud melalui jalan pelayanan publik dengan cara memaksimalkan kinerja humas.

\subsection{Pemerataan Informasi}

Komunikasi seringkali dihadapkan pada masalah dilematis. Pada satu sisi, komunikasi itu tidak bisa dihindarkan dan sangat dibutuhkan, tetapi pada sisi lain dihadapkan pada masalah pelik, seperti sulitnya menciptakan komunikasi yang efektif, terbatasnya kemampuan daya beli masyarakat dalam memanfaatkan sarana komunikasi, masih tingginya tingkat buta huruf di masyarakat sementara kemajuan teknologi komunikasi menuntut adanya kepemilikan ilmu yang mencukupi, masih banyaknya suku-suku bangsa yang memiliki bahasa sendiri, dll. Kondisi tersebut tentunya bisa menghambat pelayanan komunikasi yang diprogramkan pemerintah.

Program pemerintah ditujukan untuk masyarakat luas dengan berbagai macam latar belakang (suku, budaya, ekonomi, pendidikan, dll). Pemerintah tidak bisa mengurangi pelayanan publik karena alasan latar belakang masyarakat yang beragam dan kondisi geografis yang tidak sama. Fungsi pemerintah sebagai pelayanan masyarakat harus tetap berjalan. Humas harus bisa menampung aspirasi masyarakat untuk disampaikan pada aparatur pemerintah dan humas juga harus bisa menyampaikan kebijaksanaan pemerintah pada masyarakat

Masalah memang muncul pada heterogennya masyarakat dan kondisi geografis yang tidak sama, heterogennya masyarakat bisa memberi peluang pada penafsiran/persepsi yang berbeda mengenai kebijakan pemerintah. Latar belakang masyarakat yang berbeda memang lebih sulit menanganinya dan perbedaan ekonomi, pendidikan, suku, budaya menjadi masalah serius dalam menginformasikan kebijakan pemerintah.

Masyarakat yang kondisi ekonominya baik, cenderung akan mudah mendapatkan layanan informasi dari pemerintah karena bisa membeli segala fasilitas media informasi. Sebaliknya, masyarakat yang tidak mampu cenderung jarang/ tidak sama sekali mendapatkan layanan informasi dari pemerintah karena tidak mampu, untuk membeli media informasi. Masyarakat yang berpendidikan/ tidak buta huruf, peluang mendapatkan layanan informasi dari pemerintah mudah karena bisa membaca tetapi masyarakat yang terisolasi dan tidak berpendidikan/buta huruf sulit mendapatkan informasi dari pemerintah, karena tidak bisa membaca. Begitu juga suku, budaya, di sebagian wilayah Indonesia masih ada yang belum secara langsung bisa mendapatkan layanan informasi karena aturan-aturan yang ada pada suku atau budaya tersebut.

Letak geografis yang berbeda memunculkan masalah lain, yakni fasilitas layanan komunikasi yang tidak merata. Kondisi wilayah Indonesia yang sangat luas dan jaringan komunikasi yang belum maksimal, menambah sulitnya pemerataan fasilitas komunikasi.

Untuk meminimalkan permasalahan tersebut dan meningkatkan pemerataan informasi beberapa hal yang harus diperhatikan:

(1) Memanfaatkan teknologi komunikasi praktis dan mudah dimiliki masyarakat.

(2) Menjalin kerjasama antara pemerintah dengan lembaga swasta pengelola komunikasi.

\subsubsection{Memanfaatkan Teknologi Komunikasi}

Kemajuan teknologi komunikasi diikuti dengan kemampuan masyarakat dalam menyerap teknologi komunikasi dinilai sebagian ahli komunikasi sebagai syarat keberhasilan pembangunan. Masalahnya adalah bukan pada mampu tidaknya massyarakat menyerap/ menggunakan teknologi komunikasi tersebut tetapi pada kemampuanya untuk memiliki teknologi tersebut. Banjirnya teknologi komunikasi pada saat ini tidak diiringi kemampuan daya beli masyarakat. Pemilihan teknologi komunikasi sangat tergantung pada kondisi masyarakat. 
Terakreditasi Dirjen Dikti SK No. 56/DIKTI/Kep/2005

Secara faktual memang kondisi di masyarakat kita terjadi kesenjangan kepemilikan teknologi komunikasi. Bagi masyarakat yang hidup di kota dengan penghasilan yang lebih dari cukup dimanjakan oleh fasilitas teknologi komunikasi yang sangat mudah untuk dimanfaatkan. Sementara, masyarakat yang hidup di daerah transmigrasi/daerah pedalaman mengalami kelambatan dalam menerima teknologi komunikasi karena ketidakmampuan memilikinya padahal masyarakat yang mau tranmigrasi ini dikatakan sebagai pelopor pemerataan pembangunan. Situasi ini mengakibatkan informasi yang disampaikan pemerintah kepada masyarakat hasilnya tidak akan sama. Pelayanan publik pada sektor komunikasi tidak berhasil, artinya keberhasilan pembangunan hanya sebuah wacana saja.

Pelayanan publik harus dapat terjangkau oleh kemampuan ekonomi masyarakat, pemerintah harus mulai memperhatikan fasilitas media komunikasi yang mudah dimiliki masyarakat. Saluran radio tidak bisa menjangkau luas hingga pemerataan informasi tidak maksimal, koran masuk desa belum efektif karena masyarakat daerah pedalaman masih banyak yang masih buta huruf. Mengoptimalkan media TV pada saat ini sangat riskan karena program-progamnya banyak yang tidak sesuai dengan kultur masyarakat pedesaan, program-programnya bukan bersifat informatiflagi tetapi sudah banyak yang melenceng dari pers tanggung jawab sosial. Bahkan, TV ini cenderung labih berfungsi sebagai sebuah hiburan. William Stepenson dalam Nurudin $(2004: 190)$ mengatakan bahwa "Kodrat TV swasta itu menghibur".

Saat ini mungkin handphone sebagai tekonologi komunikasi murah yang mudah dimiliki masyarakat. Teknologi komunikasi nirmassa atau yang akrab disebut HP ini sudah merambah ke daerah-daerah pedalaman hampir di seluruh Indonesia. Keberadaan HP ini mampu mengubah pola komunikasi masyarakat pedalaman. Teknologi ini mampu mengubah cara berkomunikasi, memperoleh dan menyebarkan informasi secara cepat. Kelebihan teknologi ini bersifat dua arah timbal balik secara cepat, berbeda dengan TV atau radio yang mudah pula dimiliki tetapi tidak bersifat dua arah secara cepat dan tidak praktis. Handphone adalah teknologi yang praktis mudah dibawa ke mana-mana asalkan fasilitas jaringan telepon ini mempunyai kualitas maksimal termasuk operatornya.

Peranan operator seluler yang dikelola swasta dalam percepatan pembangunan daerah tertinggal adalah sebagai agen pembaharu (agent of communication change). Letak peranannya adalah dalam hal membantu mempercepat proses peralihan masyarakat yang tradisional menjadi masyarakat yang maju. Khususnya peralihan dari yang tadinya lambat mendapat informasi beralih ke kondisi komunikasi yang serba cepat. Tentu ini menggembirakan karena bisa membantu proses pelayanan publik pada sektor komunikasi yang tentunya juga membantu pada proses pembangunan.

Kehadiran telepon selular dalam kehidupan masyarakat merupakan harapan baru bagi pemerintah dalam meningkatkan pelayanan publik pada sektor komunikasi. Pemerintah tinggal melakukan kerjasama dengan pengelola operator selular ketika berkeinginan menyampaikan informasinya secara cepat dan mudah diterima oleh masyarakat. Memanfaatkan teknologi komunikasi yang praktis ini pemerintah tidak perlu mengeluarkan biaya banyak karena masyarakat dengan kesadaran sendiri sudah harus memilikinya karena merasakan manfaatnya sangat banyak. Melalui HP, masyarakat merasakan mudahnya bertukar informasi mengenai segala perkembangan kehidupan atau bertukar informasi mengenai segala kebijakan pemerintah, hal ini menguntungkan pemerintah karena mengarah pada pemerataan informasi secara alamiah.

\subsubsection{Kerjasama Pemerintah dengan Lembaga Swasta}

Apabila kerjasama ini menguntungkan kedua belah pihak, ke depan tidak tertutup kemungkinan, pengelola operator selular dengan pemerintah dapat membangun jaringan internet pedesaan untuk kepentingan pembangunan perekonomian (e-commerce), pendidikan (e-education), dan 
pelayanan publik (e-government). Keuntungan masyarakat dapat memanfaatkan internet mudahmudahan tidak hanya sekadar iklan saja, tetapi menjadi program pemerintah yang benar-benar harus diimplementasikan, dan ini tentunya akan menjadi nilai tambah dalam meningkatkan pelayanan publik.

Secara ekonomi (e-commerce), internet di pedesaan dapat membantu petani dan nelayan sebagai komunitas ekonomi pasar, untuk meningkatkan pengetahuan kegiatan ekonominya melalui percepatan informasi. Mereka juga dapat memperluas pasar hasil pertanian dan perikanan untuk mendapatkan hasil yang optimal. Selain itu, petani dan nelayan juga bisa berproduksi sesuai dengan permintaan pasar, karena kemudahan informasi tersebut. Dengan bantuan koneksi internet operator selular, mereka mampu meningkatkan kualitas hasil dan mengontrol supply dan demand.

Dalam bidang pendidikan (e-education), hingga saat ini semua sekolah di pedalaman belum mengenal internet. Kondisi ini menyebabkan pendidikan di daerah tertinggal sulit berkembang. Kehadiran operator selular diharapkan dapat memberikan perubahan melalui layanan teknologi komunikasi untuk mendukung proses belajar mengajar. Kebijakan pendidikan saat ini menuntut kesetaraan penguasaan pengetahuan antara sekolah di perkotaan dan di pedalaman. Internet di pedesaan yang terhubung melalui jaringan ponsel diharapkan siswa di daerah tertinggal menjadi tidak gagap terhadap teknologi dan informasi sehingga mempunyai pengetahuan yang sama dengan siswa di perkotaan.

Dalam pelayanan publik, program "mobil pintar" milik pemerintah Kab. Bandung merupakan contoh bagus dalam meningkatkan pemerataan informasi pada masyarakatnya. Pemerintah Kab. Bandung memiliki 3 (tiga) mobil pintar dengan fasilitas perpustakaan dan internet gratis. Dua dari tiga mobil tersebut berupa mobil perpustakaan dengan kapasitas 3.000 eksemplar buku dari berbagai kategori. Sedangkan satu unit mobil lainnya adalah untuk perpustakan dan telekomunikasi keliling dengan fasilitas empat unit laptop yang terhubung internet nirkabel. Para pelajar serta masyarakat umum dapat mengakses ketiga mobil tersebut secara cuma-uma setiap hari di tempat tertentu.

Namun sayang, program mobil pinar ini tidak sesuai dengan luas wilayah Kab. Bandung. Tiga mobil pintar ini harus melayani seluruh wilayah Kab. Bandung yang sangat luas sehingga satu tempat akan dikunjungi kira-kira empat kali dalam setahun. Sangat disayangkan sebuah program pelayanan komunikasi yang bagus tidak dilakukan secara optimal. Pemecahannya adalah pemerintah harus mencoba menjalin kerjasama dengan pihak swasta, perusahaan besar dengan program Corporate Social Responsibility (CSR) bisa memanfaatkan kondisi ini. Pemerintah juga harus bisa meyakinkan swasta bahwa pembangunan nasional itu bukan hanya tanggung jawab pemerintah saja, tetapi tanggung jawab semua komponen bangsa.

Meskipun penciptaan digitalisasi pelayanan publik (e-government) di pedalaman masih terbentur berbagai keterbatasan, bukan tidak mungkin untuk ke depan operator selular kerjasama dengan pemerintah mampu mengatasinya. Luasnya jaringan operator selular bila diikuti dengan pengembangan teknologi dan dukungan dari pemerintah, tidak mustahil mampu membuat sistem komunikasi online sampai ke pemerintahan desa. Dengan demikian pelayanan publik dan keunggulan-keunggulan lokal di daerah tertinggal dapat diinformasikan melalui sentra komunikasi jaringan selular.

Tersedianya fasilitas GPRS, $3 \mathrm{G}$ dan koneksi internet melalui ponsel merupakan modal pemerintah untuk membangun sarana komunikasi online di pedalaman dan meningkatkan pelayanan publik pada sektor komunikasi. Perusahaanperusahaan operator selular dan pemerintah dapat juga memanfaatkan program Corporate Sosial Responsibility (CSR) untuk pemberdayaan komunikasi masyarakat daerah tertinggal. Merupakan suatu langkah luar biasa apabila pemerintah dan pengelola operator selular mampu mengalihkan masyarakat yang tadinya gagap informasi dan teknologi beralih ke masyarakat 
Terakreditasi Dirjen Dikti SK No. 56/DIKTI/Kep/2005

melek informasi, dengan harapan mampu merubah kehidupan masyarakat daerah tertinggal yang identik dengan kebodohan dan kemiskinan berubah menjadi masyarakat pada kehidupan yang lebih baik.

\subsection{Masyarakat Diberikan Kemudahan Mendapatkan Informasi}

Sejalan dengan makin berkembangnya teknologi informasi dan kebebasan berkomunikasi, perlu disadari bahwa ternyata pemerintah belum mampu memanfatkan kemajuan teknologi informasi dan komunikasi secara optimal, baik untuk menyediakan pelayanan informasi maupun memanfaatkan teknologi informasi dalam rangka mencerdasakan kehidupan bangsa. Sejalan dengan reformasi di segala bidang termasuk dalam sistem komunikasi, pemerintah (Orde Baru) yang semula dominan sebagai penyedia dan pengatur sistem komunikasi sudah berubah menjadi fasilitator untuk terjadinya sistem komunikasi yang kondusif dan terwujudnya arus informasi yang bebas namun tetap menjaga persatuan dan kesatuan bangsa.

Melihat realitas pers kita sangat banyak dan bervariasi, pers kita banyak yang tumbuh tetapi banyak pula yang mati, pers kita ada yang profesional dan ada yang amatir. Walaupun demikian sisi positifnya adalah informasi begitu sangat mudah diperoleh, mayarakat tinggal memilih mana yang sesuai dengan keinginannya. Dalam pemerintah yang demokratis ini adalah sebuah kewajaran, tinggal bagaimana aparatur pemerintah mengelolanya. Dalam situasi ini, sebenarnya sebuah kesempatan bagi humas untuk menunjukkan kemampuan mengelola komunikasi yang baik kepada pemerintah.

Apabila humas mampu membuktikan pada pemerintah sebagai pengelola komunikasi yang baik, masyarakat seharusnya menjadi tidak bingung dengan adanya media massa dan banyak informasi yang diperoleh. Tetapi sebaliknya, masyarakat menjadi sangat terbantu dengan kondisi itu/masyarakat menjadi sangat mudah mendapatkan informasi. Humas harus bisa memberikan pelayanan kepada masyarakat mana informasi yang layak diperoleh dan mana informasi yang tidak layak. Humas harus bisa memberikan kemudahan informasi kepada masyarakat secara merata.

Kecerdasan masyarakat akan meningkatkan jika pemerataan informasi berjalan dengan baik. Meningkatnya kecerdasan masyarakat bisa dijadikan sebagai salah satu indikator berhasilnya pembangunan yang dilakukan pemerintah, selain itu bisa meningkatkan sikap kritis masyarakat. Sikap itu menggejala bisa dilihat dari makin tumbuhnya keinginan rakyat untuk mengetahui data dan informasi mengenai penyelenggaraan pemerintah dan pembangunan.

Konsep pelayanan publik bertujuan untuk memenuhi segala kebutuhan masyarakat termasuk pelayanan informasi (komunikasi). Masyarakat mempunyai hak untuk mendapatkan informasi tentang segala kebijakan pemerintah terutama mengenai keputusan-keputusan atau program-program yang akan membawa dampak atau mempengaruhi masyarakat. Penyebaran informasi kebijakan pemerintah perlu ditingkatkan terutama yang bisa menarik perhatian masyarakat. Perlu pula dijaga hubungan atau jalinan kerjasama dengan media massa dan wartawan sebagai penyebar pesan pemerintah.

Humas institusi pemerintah hendaknya memiliki sikap terbuka dalam memberikan pelayanan pada masyarakat. Perlu dihindari sikap aparat pemerintah yang sulit ditemui karena adanya prosedur dan birokrasi. Humas intitusi pemerintah harus bisa membantu dalam masalah ini walaupun yang datang dari kalangan bawah, mereka tetap harus dilayani secara baik dan tidak ada perbedaan. Pemerintah jangan mempersulit pelayanan pada masyarakat apabila ingin menciptakan pelayan yang baik (public service execellence). Aparat pemerintah adalah abdi masyarakat yang harus dapat menjadi pelayan yang baik.

Kepemimpinan berdasarkan demokrasi pancasila harus menghindarkan jauh sikap tertutup, tidak jujur dan "plin plan." Aparat pemerintah haruslah terbuka terhadap masyarakat, berani berdialog dengan rakyat dan selalu welcome terhadap usul, saran, kritik, dan pendapat dari 
masyarakat melalui jalur-jalur yang telah disepakati bersama.

Gaya, kualitas, dan kapasitas pengelola intitusi pemerintah yang diperlukan sekarang bukan hanya yang bereferensi profesionalisme saja dan wawasan kecendekiawanan yang kaku. Tetapi lebih luwes dan mampu memancarkan integritas yang dilandasi moralitas, mental ideologis, serta orintasi politik yang tepat.

Petugas pelayanan publik pada sektor komunikasi (humas) tidak perlu takut terhadap kritik dari pers sepanjang kritik itu bisa memberikan dorongan pada pelayanan publik yang lebih baik. Kritik pers yang membangun bisa dijadikan sebagai media interaksi antara pemerintah dengan masyarakat. Pemerintah dan pers hendaknya menjadi parner yang bisa menciptakan kemudahan pada masyarakat untuk mendapat informasi tentang segala program kerja pemerintah ataupun informasi mengenai kebijakan-kebijakan pemerintah.

Pers (media massa) memang menjadi penunjang penyebaran informasi yang utama, tetapi pada kenyataanya masih banyak masyarakat yang belum bisa menikmatinya. Seharusnya program Koran Masuk Desa (KMD) kalau masih ada harus lebih ditingkatkan, kalau hilang harus kembali diaktifkan. Pemerintah juga harus bisa memberikan fasilitas media laiinya (TV, Radio, Internet, dll) secara cuma-cuma kepada masyarakat. Tidak ada salahnya jika pemerintah bekerjasama dengan swasta dalam mengelola media komunikasi ini karena pihak swasta mampu menembus pelosok daerah untuk memasarkan produk komunikasinya.

Tetapi, pemerintah yang berlandaskan pada demokrasi pancasila harus menghindarkan diri dari kapitalisme informasi, pemerintah harus berorintasi pada pelayanan masyarakat. Pelayanan masyarakat pada sektor komunikasi yang dilakukan pemerintah harus bersikap terbuka, jujur, berani berdialog dengan masyarakat, memperhatikan usul, saran kritik, dan pendapat dari masyarakat. Pelayanan publik yang demikian akan menciptakan iklim yang sehat dalam mayarakat, suatu iklim di mana komunikasi dua arah timbal balik berjalan dengan baik. Melalui pelayanan komunikasi yang baik pemerintah telah menyatu dengan masyarakat.

\subsection{Terciptanya Kondisi Politik yang Stabil}

Proses komunikasi selalu berimpit dengan proses-proses lainnya. Karena itu pula tidak dapat dihindari adanya nilai-nilai kekuasaan/sistem politik yang tidak cocok dengan sistem komunikasi. Kondisi sistem komunikasi Indonesia selalu berubah-rubah hal ini dipengaruhi oleh kondisi sosial politik dan peran penguasa pemerintah. Mulai jaman kepemimpinan Presiden Soekarno, Soeharto, Habibi, Abdurahman Wahid, Megawati, Susilo Bambang Yudhoyono, kondisi sistem Komunikasi Indonesia yang dikelola pemerintah tidak pernah mempunyai pelayanan komunikasi yang memuaskan.

Padazaman Presiden Soekarno, pengelolaan komunikasi masih sangat tergantung pada kondisi pemerintah karena memang pemerintah Indonesia belum lama merdeka, pengelolaan komunikasi yang paling sering dilakukan hanya sebatas sosialisasi pembentukan lembaga-lemabaga pemerintah dan rencana-rencana konsolidasi di dalam struktur pemerintahan.

Zaman Presiden Soeharto penerbitan surat kabar, dan media elektronik, sangat dibatasi. Susah sekali untuk menerbitkan media massa dan harus mendapatkan SIUPP (Surat Ijin Usaha Penerbitan). Kalau tidak memiliki modal besar dan tidak mempunyai hubungan/kenalan dengan pejabat Departemen Penerangan, semakin sulit untuk mendirikan perusahaan penerbitan pers. Isi pesan dalam media massa selalu dikontrol/diawasi oleh pemerintah. Pada masa ini Departemen Penerangan menjadai corong informasi pemerintah sekaligus kendaraan politik Partai Golkar.

Pada zaman Presiden Habibie, Menteri Penerangan Yunus Yosfiah mencabut SIUPP yang berdampak mulai bermunculan media-media baru dengan isi pesan yang tidak terkontrol. Zaman Presiden Abdurahman Wahid, Departemen Penerangan dibubarkan dan kebebasan isi pesan dalam media massa semakin tidak terkontrol dengan dalih kebebasan mengeluarkan pendapat. Zaman Presiden Megawati, Departemen Penerangan dimunculkan kembali, namun berubah dalam 
Terakreditasi Dirjen Dikti SK No. 56/DIKTI/Kep/2005

pengelolaan dan nama departemenya. Namanya menjadi Departemen Informasi dan Komunikasi. Depertemen ini tidak lagi menjadi corong informasi yang utama seperti pada zaman Presiden Soeharto, karena sudah banyak media komunikasi sebagai informasi yang mudah dijangkau oleh masyarakat.

Jaman presiden Susilo Bambang Yudhoyono sistem komunikasi tidak berbeda dengan kepemimpinan presiden sebelumnya pada era reformasi (Abdurrahman Wahid, Megawati). Namun, pada saat menjelang pemilu, banyak bermunculan media massa baru yang isi pesannya tidak untuk kepentingan masyarakat luas, tetapi lebih mementingkan informasi mengenai programprogram partainya. Ini berarti pelayanan informasi menjadi tidak wajar kalau kita berpedoman pada fungsi media massa. Fungsi media massa, salah satunya, adalah untuk kepentingan masyarakat secara menyeluruh. Pada saat ini, Departemen Informasi dan Komunikasi di bawah tanggung jawab pemerintah tidak bisa berbuat apa-apa takut dituduh intervensi pada kepentingan partai.

Kondisi tersebut, tentunya, tidak menciptakan sebuah pelayanan komunikasi yang diharapkan masyarakat. Pelayanan komunikasi yang baik adalah yang bisa memenuhi kebutuhan informasi secara merata, tidak berpihak pada salah satu golongan, ada koordinasi antara pemerintah dengan partai politik, ada koordinasi dengan lembaga swasta yang mengelola komunikasi, ada koordinasi dengan hali-ahli komunikasi. Koordinasi ini penting untuk menciptakan saling pengertian/ pemahaman yang sama mengenai semua kebijakan komunikasi yang akan disampaikan pada masyarakat. Semua pengelola komunikasi tersebut harus juga bisa mendukung sistem pers Pancasila yang memperhatikan aspek budaya, ideologi, dan menghindarkan diri dari unsur-unsur liberalisme dan kapitalisme.

Komunikasi yang efektif, syaratnya antara komunikator dan komunikan memiliki keinginan yang sama. Apabila diibaratkan pemerintah adalah sebagai komunikator (pelayan masyarakat) dan masyarakat adalah komunikan, maka proses komunikasi itu akan sangat rumit, penuh dengan berbagai kepentingan. Tidak mudah memang pemerintah Indonesia menempatkan posisinya sesuai dengan kondisi masyarakatnya yang sangat heterogen. Dalam kondisi ini, pemerintah harus melihat dimensi isi dan dimensi hubungan. Mulyana, (2000: 99) mengatakan, dimensi isi disandi secara verbal, sementara dimensi hubungan disandi secara nonverbal. Dimensi isi menunjukkan muatan (isi) komunikasi, yaitu apa yang dikatakan. Sedangkan dimensi hubungan menunjukkan bagaimana cara mengatakannya yang juga mengisyaratkan bagaimana hubungan peserta komunikasi itu, dan bagaimana seharusnya pesan itu ditafsirkan.

Dalam dimensi isi, strategi penyampaian pesan harus menjadi fokus perhatian pemerintah. Pengaruh pesan yang disampaikan bisa ditafsirkan berbeda apabila cara penyampaiannya berbeda. Misalnya, informasi kebijakan pemerintah yang disampaikan presenter televisi yang pandai mendramatisir suasana pendengar, akan mempunyai pengaruh yang lebih kuat pada masyarakat. Jika dibandingkan dengan penyajian tulisan di koran. Isi kebijakan yang menguntungkan masyarakat yang disampaikan pejabat pemerintah menjelang Pemilu bisa ditafsirkan sebagai sebuah kampanye, walaupun kebijakan tersebut sudah lama disahkan oleh anggota dewan.

Dalam dimensi hubungan, pemerintah harus berhati-hati menunjuk juru bicara pemerintah. Sebaiknya, pemerintah mempunyai juru bicara yang tidak berlatar belakang partai politik dan bukan berasal dari keluarga pejabat. Dia harus nasionalis sejati yang betul-betul mementingkan negara dan rakyatnya. Ini untuk menghindari tuduhan kalau kebijakan yang disampaikannya adalah untuk kepentingan partainya atau keluarganya. Pelayanan komunikasi yang disampaikan untuk kepentingan semua golongan, untuk kepentingan semua masyarakat.

Semua aktivitas pelayanan komunikasi yang dilakukan pemerintah terhadap masyarakatnya mengandung potensi konflik, apalagi pemerintah Indonesia memiliki berbagai budaya. Respons yang terjadi pada situasi ini bisa bervariasi. Pemerintah harus bisa menunjuk komunikator yang memahami budaya komunikannya. Situasi 
komunikasi yang tepat pada kondisi ini adalah model komunikasi humanistik (Mulyana, 2004: 5). Model komunikasi humanistik mengasumsikan bahwa pihak-pihak yang terlibat dalam komunikasi adalah setara (sama-sama disebut komunikator), dan mengakui bahwa kata-kata dan perilaku nonverbal yang sama dapat dimaknai secara berbeda oleh orang-orang yang berbeda budaya.

Pelayan publik yang baik tentunya akan tercapai jika pelayanan yang diberikan memperhatikan kondisi tersebut. Kondisi masyarakat Indonesia memang beragam, tetapi apabila ada kesadaran bersama bahwa pelayan publik ini menjadi tanggung jawab bersama, insya Allah cita-cita untuk menciptakan pelayanan publik yang baik akan tercapai.

Berkaitan dengan situasi komunikasi di Indonesia Astrid S. Susanto dalam bukunya Komunikasi Sosial di Indonesia (1985), menawarkan dua pendekatan komunikasi sosial dalam lingkungan bangsa (pemerintah), yaitu; (1) mengaitkan sistem masukan-luaran (input-output system ) dengan sistem tuntutan dan pelayanan (demand-supply system), konsep ini disebut juga dengan teknik komunikasi langsung dengan masyarakat; (2) teknik komunikasi tidak langsung.

Sistem yang pertama, memungkinkan dinamika dan adanya penyesuaian diri antara pemerintah dengan masyarakat setiap saat secara timbal balik sesuai dengan perubahan zaman. Komunikasi dua arah timbal balik terjamin dalam pendekatan ini, sehingga dalam kegiatan-kegiatan negara, pemerintah akan memperoleh dukungan dan pengertian dari masyarakat. Dengan selalu berkomunikasi dengan masyarakat, pemerintah akan mengetahui apa yang dirasakan sebagai hal yang meresahkan, sehingga permasalahan terpecahkan sebelum kestabilan terganggu. Sistem ini sering dimanfatkan oleh pemerintah dalam bentuk teleconference antara kepala negara dengan rakyatnya.

Sistem yang kedua, adalah teknik tidak langsung. Sistem ini komunikasi yang dilakukan dari masyarakat kepada pemerintah selalu melalui wakilnya. Sistem ini berkaitan dengan teori komunikasi arus dua tahap, (Haroldsen dan Blake, (2005 : 152). Informasi sering mengalir dari media massa kepada orang yang berpengaruh (pemuka pendapat) dan dari mereka kepada temantemannya yang kurang aktif dan dapat dipengaruhi. Teori ini masih cocok dengan kondisi masyarakat di kita, terutama pada masyarakat pedalaman yang masih terisolir dan masyarakatnya masih jauh dari terpaan informasi. Kepala suku atau kepala adat menjadi tumpuan utama pemberi informasi dan penyampai informasi kepada pemerintah. Pada lembaga yang formal Dewan Perwakilan Daerah (DPRD) dijadikan sebagai mediator perantara komunikasi masyarakat dengan pemerintah. Pemerintah yang bijaksana tentunya menggunakan kedua sarana dan saluran komunikasi tersebut. Semua ini dilakukan sebagai upaya untuk memperoleh pelayanan publik pada sektor komunikasi yang bagus sehingga mampu menciptakan pembangunan nasional secara adil dan kestabilan negara.

\section{Daftar Pustaka}

\section{A. Buku}

Budiarjo, Miriam. 1996. Demokrasi di Indonesia, Gramedia Pustaka Utama. Jakarta

Cutlip, Center, Broom. 2005. Effective Public Relations Merancang dan Melaksanakan Kegiatan Kehumasan dengan Sukses, Edisi Bahasa Indonesia. Gramedia, Jakarta

Haroldesen, Edwin \& Blake, Reed, Blake. Taksonomi Konsep Komunikasi, Alih Bahasa Hasan Bahanan. Papyrus, Surabaya

Iriantara, Yosal. 2004. Manajemen Strategis Public Relations, Ghalia Indonesia, Jakarta.

Mulyana, Deddy. 2000. Ilmu Komunikasi Suatu Pengantar, Rosda Karya, Bandung

2004. Komunikasi Efektif Suatu Pendekatan Lintas Budaya, Rosda Karya, Bandung. 
Terakreditasi Dirjen Dikti SK No. 56/DIKTI/Kep/2005

\section{B. Lain-lain}

Napitupulu, Paimin. 2007. Pelayan Publik \& Pikiran Rakyat Edisi Sabtu 5 Januari 2008 Costumer Satisfaction, Alumni, Bandung.

Widjaja, H.AW. 1997. Komunikasi dan Hubungan Masyarakat, Bumi Aksara, Jakarta.

Pikran Rakyat Edisi Kamis 17 Januari 2008

Hhtp://percikapikiran-badri.blogspot.com/2007/ 11/artikel.html 
